\title{
Correction:Clinical and genetic characterization of chanarin-dorfman syndrome patients: first report of large deletions in the ABHD5 gene
}

\author{
Chiara Redaelli ${ }^{1}$, Rosalind A Coleman², Laura Moro ${ }^{3}$, Amalia Sertedaki ${ }^{4}$, Talia Kakourou${ }^{4}$, Solaf Mohamed Elsayed ${ }^{5}$, \\ Daniele Prati ${ }^{6,7}$, Agostino Colli ${ }^{8}$, Donatella Mela ${ }^{9}$, Roberto Colombo ${ }^{10}$, Daniela Tavian ${ }^{1 *}$
}

\section{Correction}

Following the publication of this article [1], it was clarified that the clinical follow-up of one of CDS family described in the manuscript was performed by Dr. Amalia Sertedaki and Talia Kakourou. The authorship of the article has been changed accordingly. The submitting authors would like to apologise to Amalia Sertedaki and Talia Kakourou for this error and they would like to thank Catherine Dacou-Voutetakis for underlining the problem.

\begin{abstract}
Author details
'Department of Psychology, Catholic University of the Sacred Heart, Milan, Italy. ${ }^{2}$ Department of Nutrition, University of North Carolina, Chapel Hill, NC, USA. ${ }^{3}$ DiSCAFF Department, University of Piemonte Orientale, Novara, Italy. ${ }^{4}$ Department of Paediatrics, Athens University, Greece. ${ }^{5}$ Medical Genetics Center, Korba, Cairo, Egypt. ${ }^{6}$ Department of Transfusion Medicine and Hematology, Ospedale Alessandro Manzoni, Lecco, Italy. ${ }^{7}$ Center of Transfusion Medicine, Cellular Therapy and CryoBiology, IRCCS Foundation Ca' Granda Ospedale Maggiore Policlinico, Milan, Italy. ${ }^{8}$ Department of Internal Medicine, Ospedale Alessandro Manzoni, Lecco, Italy. ${ }^{9}$ Department of Internal Medicine, Santa Corona Hospital, Pietra Ligure, Italy. ${ }^{10}$ Institute of Biochemistry and Clinical Biochemistry, Catholic University, Gemelli Hospital, Rome, Italy.
\end{abstract}

\section{Authors' contributions \\ CR carried out the molecular genetic studies and the interpretation of the results. RAC and LM made substantial contributions to interpretation of data and participated in manuscript preparation. AS, TK, SME, DP, AC and RC were involved in the clinical evaluation of patients and manuscript revision. DT made substantial contributions to conception, analysis and interpretation of data and drafted the manuscript. All authors read and approved the final manuscript.}

\section{Competing interests}

The authors declare that they have no competing interests.

Received: 15 February 2011 Accepted: 21 February 2011

Published: 21 February 2011

\footnotetext{
* Correspondence: daniela.tavian@unicatt.it

'Department of Psychology, Catholic University of the Sacred Heart, Milan, Italy

Full list of author information is available at the end of the article
}

\section{Reference}

1. Redaelli C, Coleman RA, Moro L, Dacou-Voutetakis C, Elsayed SM, Prati D, Colli A, Mela D, Colombo R, Tavian D: Clinical and genetic characterization of Chanarin-Dorfman Syndrome patients: first report of large deletions in the ABHD5 gene. Orphanet J Rare Dis 2010, 5:33.

doi:10.1186/1750-1172-6-6

Cite this article as: Redaelli et al:: Correction:Clinical and genetic characterization of chanarin-dorfman syndrome patients: first report of large deletions in the ABHD5 gene. Orphanet Journal of Rare Diseases 2011 6:6.
Submit your next manuscript to BioMed Central and take full advantage of:

- Convenient online submission

- Thorough peer review

- No space constraints or color figure charges

- Immediate publication on acceptance

- Inclusion in PubMed, CAS, Scopus and Google Scholar

- Research which is freely available for redistribution 